\title{
Nanochemopreventive effect of polymer functionalized gold nanoparticles containing hesperetin drug inhibited proliferation and induced apoptosis in Hep3B cells
}

\author{
Gokuladhas Krishnan*, Jayakumar Subramaniyan, Pramila Chengalvarayan Subramani, Devaki Thiruvengadam \\ Department of Biochemistry, University of Madras, Guindy Campus, Chennai 600 025, Tamilnadu, India.
}

\begin{tabular}{l} 
ARTICLE INFO \\
\hline Article history: \\
Received on: $27 / 09 / 2016$ \\
Revised on: $17 / 10 / 2016$ \\
Accepted on: 10/11/2016 \\
Available online: $28 / 12 / 2016$ \\
\hline Key words: \\
Nanochemoprevention, Gold \\
nanoparticles, Hesperetin, \\
Hep3B cells.
\end{tabular}

ARTICLE INFO

Article history:

ceived on: $27 / 0$

Accepted on: 10/11/2016

Key words:

Hep3B cells.

\begin{abstract}
To investigate the potential biomedical applications of Polymer functionalized gold nano particles for predictive, preventive and personalised nanomedicine in liver cancer. The present study is designed to evaluate the nanochemopreventive effect of hesperetin conjugated gold nanoparticles ( $\left.\mathrm{Au}-\mathrm{mPEG}_{(5000)} \mathrm{S}-\mathrm{HP}\right)$ involved in proliferation and induced apoptosis in Hep3B cells. We have previously reported that well synthesized and

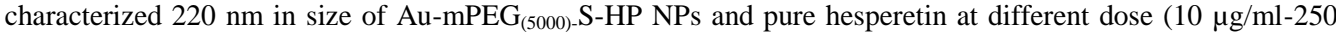
$\mu \mathrm{g} / \mathrm{ml}$ ) on Hep3B cells for $48 \mathrm{~h}$ by MTT assay. Pure hesperetin and Hesperetin loaded gold nanoparticles (AumPEG (5000)-S-HP NPs) were inhibited the growth of Hep3B cells in a dose dependent manner. The $\mathrm{IC}_{50}$ value of pure hesperetin is $63.18 \mu \mathrm{g} / \mathrm{ml}$ and the $\mathrm{IC}_{50}$ value of when compare with Au-mPEG ${ }_{(5000)}-\mathrm{S}-\mathrm{HP}$ NPs is $44.3 \mu \mathrm{g} / \mathrm{ml}$. The classified apoptotic and non-apoptotic cells were identified in PI staining and EB/AO staining. Immunoblotting results showed that the protein expression of cell cycle checkpoint protein p53 and proapoptotic protein Bax, Cyt-c and caspase-3 were up-regulated while the matrix metalloproteinases MMPs 2/9, inflammatory and proliferative markers NF-kB, PCNA and Cyclin D1 was down-regulated and the antiapoptotic protein Bcl-2 and Survivin significantly increase the expression in hesperetin conjugated gold nanoparticles treated cells. Moreover our data demonstrated that Au-mPEG ${ }_{(5000)-} \mathrm{S}-\mathrm{HP}$ nanoparticles treated inhibit proliferation and induced apoptosis in human liver cells. Treatment of hesperetin conjugated gold (Au$\left.\mathrm{mPEG}_{(5000)-} \mathrm{S}-\mathrm{HP}\right)$ nanoparticles increase the proportion of cells with reduced DNA content (sub $\mathrm{G}_{0}-\mathrm{G}_{1}$ peak) indicative of apoptosis with loss of cells in the $\mathrm{G}_{1}$ phase.
\end{abstract}

\section{INTRODUCTION}

Hepatocellular carcinoma (HCC) is the most frequently occurring malignancies in leading countries, and it is fifth most commonly diagnosed cancer in men and the seventh in women worldwide. The HCC is the second most frequent cause of death in men and sixth most leading cause of death in women (Jemal et al., 2001) and is responsible for an estimated 700,000 deaths annually. Moreover eighty percentage of the cases of HCC occur in East and Southeast Asia, China as well as middle and West

* Corresponding Author

Email: gokul_bt@yahoo.com
Africa have the highest prevalence of $\mathrm{HCC}$, mainly due to increasing rates of viral infection (Hepatitis B \& C) and cirrhosis (alcoholism being the most common cause of hepatic cirrhosis) (Singhal et al., 2012 and Tsai et al., 2010). The established risk factors for hepatocellular carcinoma include Hepatitis B or C viruses (HBV and $\mathrm{HCV}$ ) infection, alcohol drinking, tobacco smoking, and aflatoxin. The high risk factors for liver cancer include diet, obesity, diabetes and insulin resistance, use of oral contraceptives, iron overload (London et al., 2006). The treatment of HCC is still a big challenge in medicine, most patients with HCC present at an advanced stage when successful surgical treatment is no longer feasible, and current therapeutic options achieve clinical responses in only a small percentage of people (Wellington et al., 2001). 
Chemoprevention serves as an attractive alternative to control malignancy. The recent approach of chemoprevention is entirely prevented, slowed or reversed substantially by the administration of one or more non-toxic naturally occurring and/or synthetic agent, otherwise called as anticarcinogen (Devanand Venkatasubbu et al., 2015). The increase in the use of synthetic chemicals in cancer therapy has led to many side effects, poor bioavailability and undesirable hazards; there is worldwide trend to go back to natural resources (medicinal plants) which are therapeutically effective, culturally acceptable and economically within the reach of the poor people (Fauziah et al., 2005). The search for new compounds in foods or in plant medicines showing anticancer effects is one realistic and promising approach to prevention. According to the World Health Organization (WHO) primary health care is still relied upon the natural products and approximately $80 \%$ of the residents of developing countries in the world use natural products as foods medicines. An example of the dominant role of natural products can be seen in the last 25 years, where the $77.8 \%$ of the cancer therapeutic of approved drugs are either natural products or based on natural products, or mimics of natural products (Formica and Regelson, 1995). Hesperetin (3', 5, 7-Trihydroxy-4-methoxy flavanone) with molecular weight about 302.3; it is a flavonoid that exists widely in plants, fruits, flowers, foods of plant origin and abundant in citrus fruits (Wilcox et al., 1999). The drug hesperetin is an important bioactive compound in medicinal herbs and it also has biological and pharmacological activities, such as anticarcinogenic effect, antihypertensive, antiinflammatory, antioxidant and lipid-lowering efficacy (Karkabounas et al., 1996). Since many antioxidants exhibit antiplatelet and anticarcinogenic effects (Horvathova et al., 2006) it is possible that hesperetin can also function in a similar way. This drug is already report that it shows anti-carcinogenic effects caused in cancers like colon, breast which is strongly supported by an in vitro and in vivo studies (Aranganathan and Nalini, 2009).

Inspite of the wide spectrum of pharmacological properties, the use of hesperetin in pharmaceutical fields is limited due to its aqueous solubility and slow dissolution rate from solid oral forms, thus restricting its use in chemotherapy (Kanaze et al., 2006). Most current anticancer drugs do not greatly differentiate between cancerous and normal cells, leading to systemic toxicity and adverse side effects and also poor bioavailability, poor permeability, instability and extensive first pass metabolism before reaching systemic circulation. Among these, polymer functionalised nanoparticles offers promising enhanced therapeutic performance of anticancer drugs by increasing their aqueous solubility, increasing bioavailability and permeability. Due to their small size, nanoparticles penetrate into even small capillaries and are taken up with in cells allowing an efficient drug accumulation at the targeted sites in the body (Devanand Venkatasubbu et al., 2013).

Nanoparticles applied as drug delivery systems can include liposomes, other polymeric NPs, and inorganic NPs. The Polymeric Nanoparticles (PNPs) are prepared from biocompatible and biodegradable polymers in size between $10-1000 \mathrm{~nm}$ where the drug is dissolved, entrapped, encapsulated or attached to a nanoparticle matrix. The Most NPs are easily cleared by the reticuloendothelial system (RES) or mononuclear phagocytic system (MPS) (Sunderland et al., 2006). In addition to polymerbased micelles, inorganic silica and metallic nanoparticles have been broadly used as vehicles for selective targeting and drug delivery to hepatic cancer cells in vitro and in vivo (Li et al., 2010) developed multi-layered PEGylated silica Nanoparticles (SN) loaded with 32 mole\% Docetaxel (Dtxl), and showed 50\% release of the loaded Dtxl after 40 hours in $37^{\circ} \mathrm{C}$ PBS buffer. When developing nanoparticles for drug delivery, it is of crucial importance to understand the mechanism of interaction between the nanoparticles and cells and the mechanism of delivery of the encapsulated drug to achieve efficient delivery and release of drugs to the target. Interactions between cells and nanoparticles and the mechanisms for intracellular drug delivery have been investigated for various nanoparticles (Xu et al., 2009; Panyam and Labhasetwar, 2003 and Nam et al., 2009). In most cases, endocytosis of the nanoparticles is the main mechanism for internalization (Lin et al., 2014), and subsequently the drug has to be released from the nanoparticle. Polymeric nanoparticles can employ various release mechanisms such as diffusion of the load, matrix swelling, and polymer erosion, partition of the load, or a burst release effect depending on properties of the polymer and of the payload (Kumari et al., 2010). To be effective, drugs internalized by endocytosis of the nanoparticles depend on endosomal escape to reach the cytosol, to avoid lysosomal degradation (Panyam et al., 2002). In our previous study we introduce a new method for effective drug delivery system to improve the drug efficacy, solubility and bioavailability with the help of nanomaterials by synthesizing gold $(\mathrm{Au})$ nanoparticles (NPs) stabilized and reduced with functionalized polymer O-[2-(3mercaptopropionylamino)ethyl]-O'-methyl polyethylene glycol $\left(\mathrm{mPEG}_{(5000)-\mathrm{SH}}\right)$. Further, it is capped with anticancer drughesperetin (HP) for effective drug delivery to treat hepatocellular carcinoma in vitro (Gokuladhas et al., 2014). From the continuation of the above study now here we aim to divulge the Nanochemopreventive effect of polymer functionalised gold ( $\mathrm{Au}$ $\left.\mathrm{mPEG}_{(5000)} \mathrm{S}-\mathrm{HP}\right)$ nanoparticles loaded hesperetin drug inhibited proliferation and induced apoptosis in the human hepatocellular carcinoma cell line Hep3B.

\section{MATERIALS AND METHODS}

\section{Chemicals}

$\begin{array}{lcccr}\text { Minimum Essential Medium (MEM), } & 0.25 \% & \text { Trysin- } \\ \text { EDTA solution, Fetal bovine serum } & \text { (FBS) and }\end{array}$ antibiotic/antimycotic solution were from (HiMedia) India. Bovine serum albumin (BSA), Propodium iodide, Ethidium bromide, Acridine orange were obtained from Bangalore GeNei (Bangalore, India). Primary antibodies against p53, Cyt c, Bax, PCNA, Cyclin D1, Caspase 3 and Bcl-2 were purchased from Santa cruz biotechnology; Survivin, NF-kB MMP-2 and MMP-9 were provided as a kind gift by Dr. R. Shenbhagaraman, CAS in 
Botany, India HRP-labelled secondary antibodies were purchased from Genei, Bangalore, India.

\section{Cell Line}

Human hepatocellular carcinoma - Hep3B was procured from National Centre for Cell Sciences (NCCS), Pune, India. The cells were grown in T75 culture flask containing MEM supplemented with $10 \%$ FBS. Upon reaching confluence, the cells were detached using Trypsin-EDTA solution.

\section{Experimental Protocol}

Based on MTT assay we selected the doses $44.3 \mu \mathrm{g} / \mathrm{ml}$ Au-mPEG ${ }_{(5000)-}$ S-HP nanoparticles treated at 48 hours.

Group 1: Control Hep3B cells treated with $0.1 \%$ DMSO.

Group 2: Hep3B cells treated with $63.18 \mu \mathrm{g} / \mathrm{ml}$ of pure hesperetin for 48 hours.

Group 3: Hep3B cells treated with $44.3 \mu \mathrm{g} / \mathrm{ml}$ of $\mathrm{Au}-$ $\mathrm{mPEG}_{(5000)} \mathrm{S}-\mathrm{HP}$ nanoparticles for 48 hours.

\section{Assessment of Nuclear Morphology by Propdium Iodide (PI) Staining}

The propidium iodide staining was carried out by the method of Chandramohan et al., (Chandramohan et al., 2007). Hep3B cells were plated at a density of $5 \times 10^{4}$ in 6 well plates containing sterile cover slips. They were allowed to grow at $37^{\circ} \mathrm{C}$ in a humidified $\mathrm{CO}_{2}$ incubator until they are $70-80 \%$ confluent. Then cells were treated with $63.18 \mu \mathrm{g} / \mathrm{ml}$ of pure hesperetin and $44.3 \mu \mathrm{g} / \mathrm{ml}$ of Au-mPEG${ }_{(5000)} \mathrm{S}-\mathrm{HP}$ nanoparticles for $48 \mathrm{~h}$. The culture medium was aspirated from each well and the cells were gently rinsed twice with $\mathrm{PBS}$ at room temperature, fixed in methanol: acetic acid $(3: 1 \mathrm{v} / \mathrm{v})$ for $10 \mathrm{~min}$ and stained with 50 $\mu \mathrm{g} / \mathrm{ml}$ propidium iodide for $20 \mathrm{~min}$. Nuclear morphology of apoptotic cells with condensed /fragmented nuclei was examined under a fluorescent microscope and at least $1 \times 10^{3}$ cells were counted for assessing apoptotic cell death.

\section{Ethidium Bromide/Acridine Orange Staining (EB/AO Staining or Dual Staining)}

$\mathrm{EB} / \mathrm{AO}$ staining was carried out by the method of Gohel et al., (Gohel et al., 1999). Hep3B cells were plated at a density of $5 \times 10^{4}$ in 6 well plates containing sterile cover slips. They were allowed to grow at $37^{\circ} \mathrm{C}$ in a humidified $\mathrm{CO}_{2}$ incubator until they are $70-80 \%$ confluent. Then cells were treated with $63.18 \mu \mathrm{g} / \mathrm{ml}$ of pure hesperetin and $44.3 \mu \mathrm{g} / \mathrm{ml}$ of $\mathrm{Au}_{-\mathrm{mPEG}_{(5000)-} \mathrm{S}-\mathrm{HP}}$ nanoparticles for $48 \mathrm{~h}$. The culture medium was aspirated from each well and the cells were gently rinsed twice with PBS at room temperature, Then the cover slips were taken and kept on glass slides and stained with $100 \mu$ of dye mixture (1:1 of EB and AO), immediately viewed under fluorescence microscope. Viable cells had green fluorescent nuclei with organized structure. The early apoptotic cells had yellow chromatin in nuclei that were highly condensed or fragmented. Apoptotic cells also exhibited membrane blebbing. The late apoptotic cells had orange chromatin with nuclei that were highly condensed and fragmented. The necrotic cells had bright orange chromatin in round nuclei. Only cells with yellow, condensed, or fragmented nuclei were counted as apoptotic cells in a blinded, nonbiased manner. For each sample, at least 500 cells/well and 4 wells/condition were counted, and the percentage of apoptotic cells was determined [\% of apoptotic cells $=$ (total number of apoptotic cells/total number of cells counted) $\mathrm{x} 100]$.

\section{Western Blot analysis}

Western blot analysis for protein expression in HepG2 cells were done by following method. Approximately $50 \mu \mathrm{g}$ protein of the total cell lysate was mixed with equal volume of $2 \mathrm{x}$ sample buffer, boiled for 5 minutes at $95^{\circ} \mathrm{C}$, cooled, loaded on each lane of $8-15 \%$ polyacrylamide gel, and separated by sodium dodecyl sulphate-polyacrylamide gel electrophoretically transferred to Nitrocellulose membranes. The membranes were then blocked in 5\% non-fat milk in Tris-buffered saline with $0.1 \%$ Tween 20 for $1 \mathrm{hr}$ at room temperature, and probed with the following primary antibodies: p53 [rabbit polyclonal antibody at a dilution of 1: 1000]; Bax [rabbit polyclonal antibody at a dilution of 1: 500]; Bcl-2 [rabbit polyclonal antibody at a dilution of 1:500]; Survivin [mouse monoclonal antibody at a dilution of 1:500]; Cyt-C [mouse monoclonal antibody at a dilution of 1:500]; active caspase-3 [goat polyclonal antibody at a dilution of 1:250]; Cyclin D1 [mouse monoclonal antibody at a dilution of 1:500]; MMP-2 \& MMP-9 [rabbit polyclonal antibody at a dilution of $1: 500$ ]; PCNA [mouse monoclonal antibody at a dilution of 1:1000]; NF-kB [rabbit monoclonal antibody at a dilution of $1: 500$ ]; $\beta$-Actin [mouse monoclonal antibody at a dilution of 1:2000] overnight at $4^{\circ} \mathrm{C}$. The blots were then extensively washed with Tris-buffered saline with $0.1 \%$ Tween 20 and then incubated with respective (anti mouse and anti rabbit) HRP labelled secondary antibody (Genei, Bangalore, India) at a dilution of 1:2000 for $1 \mathrm{hr}$ at room temperature. After extensive washes in TBS-T, the bands were visualized by treating the membranes with 3, 3'-diaminobenzidine tetrahydrochloride (SRL, Mumbai, India). The membranes were then photographed and quantitated with image $j$ image analysis software, NIH, USA. Densitometry data presented in bar graphs are "Fold change" as compared with control in each case.

\section{Flow Cytometry analysis}

Flow cytometric analysis was carried out as described by Rasola \& Geuna (Rasola et al., 2001). Briefly, $1 \times 10^{6}$ cells were plated in $100 \mathrm{~mm}$ Petri dishes with MEM containing $10 \%$ FBS. Cells were incubated for $48 \mathrm{~h}$ in $5 \% \mathrm{CO}_{2}$ and $95 \%$ air at $37^{\circ} \mathrm{C}$. Control cells received $0.1 \%$ dimethyl sulphoxide (DMSO) containing MEM, and pure hesperetin-treated cells received 63.18 $\mu \mathrm{g} / \mathrm{ml}$ and Au-mPEG${ }_{(5000)-S-H P}$ nanoparticles-treated cells received $44.3 \mu \mathrm{g} / \mathrm{ml}$ for $48 \mathrm{~h}$. After $48 \mathrm{~h}$, the cells were trypsinized and combined with floating cells in the medium they were used for flow cytometry assay. The treatment protocol is as follows: $1 \times 10^{6}$ cells were taken from control and from hesperetin treated plates 
were centrifuged at $1000 \mathrm{~g}$ for $5 \mathrm{~min}$. Supernatant was removed and cells were washed twice with PBS. The pellet was resuspended in approximately $500 \mu \mathrm{l}$ of ice-cold PBS and cells were mixed by aspiration 20 times using a pipette. Cells were fixed by adding $5 \mathrm{ml}$ of cold ethanol drop by drop and were kept at $-20^{\circ} \mathrm{C}$ overnight. After overnight fixation, ethanol was removed by centrifuging at $1000 \mathrm{~g}$ for $10 \mathrm{~min}$. The pellet was washed twice with PBS $+1 \%$ BSA (ethanol-fixed cells were difficult to pellet; adding BSA or serum to the wash medium overcame this). The pellet was resuspended in $800 \mu$ l of PBS containing $1 \%$ BSA. $100 \mu \mathrm{l}$ of $10 \times$ propidium iodide solution was added $(500 \mu \mathrm{g} / \mathrm{ml}$ propidium iodide in PBS, $\mathrm{pH} 7.4$ ) and $100 \mu \mathrm{l}$ of RNase A was added $(10 \mathrm{mg} / \mathrm{ml}$ prepared in $10 \mathrm{~mm}$ Tris-Cl, $\mathrm{pH} \mathrm{7.5)}$ and incubated at $37^{\circ} \mathrm{C}$ for $30 \mathrm{~min}$. Cell-cycle analysis was performed using a Beckman vantage flow cytometer and quantification of cell cycle distribution was performed using Multi-cycle software (Phoenix Flow System, San Diego, CA, USA). Percentage of cells in the different cell-cycle phases was assessed.

\section{Statistical analysis}

All the grouped data were significantly evaluated with SPSS/10 software. Hypothesis testing methods included one way analysis of variance (ANOVA) followed by least significant difference (LSD) test. $\mathrm{P}$ values of less than 0.05 were considered to indicate statistical significance. All these results were expressed as mean \pm S.D $(n=3)$.

\section{RESULTS}

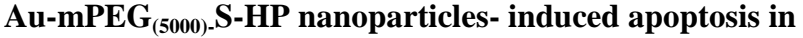 Hep3B cells}

Figure 1 depicts the morphological changes in control, pure hesperetin (HP) and Au-mPEG ${ }_{(5000)-} \mathrm{S}-\mathrm{HP}$ nanoparticles treated Hep3B cells under fluorescence microscopy after staining with ethidium bromide/acridine orange. Fig 1(a) Control Hep3B cells shows normal morphology of viable cells with green fluorescence nuclei. Pure hesperetin treated cells at $63.18 \mu \mathrm{g} / \mathrm{ml}$ after $48 \mathrm{~h}$ are under early apoptotic indicated by yellow fluorescent nuclei Fig 1(b). In Fig 1 (c) shows the Au-mPEG ${ }_{(5000)-S}-H P$ nanoparticles-treated cells received $44.3 \mu \mathrm{g} / \mathrm{ml}$ for $48 \mathrm{~h}$ are under late apoptotic/dead cells indicated by orange fluorescent nuclei. The percentage of apoptotic cells after treatment with pure hesperetin with $63.18 \mu \mathrm{g} / \mathrm{ml}$ and $\mathrm{Au}_{-\mathrm{mPEG}_{(5000)} \mathrm{S}-\mathrm{HP}}$ nanoparticles-treated cells with $44.3 \mu \mathrm{g} / \mathrm{ml}$ at $48 \mathrm{~h}$ shows increased $(p<0.05)$ enormously. Figure 2 shows the morphological changes in control, pure hesperetin treated and $\mathrm{Au}_{-\mathrm{mPEG}_{(5000)} \mathrm{S}-\mathrm{HP}}$ nanoparticles-treated cells by fluorescence microscopy after staining with propidium iodide. Fig 2(a) shows the morphological changes in control shows clear nuclei. The highly condensed and fragmented nuclei that are the index of apoptosis were observed at $63.18 \mu \mathrm{g} / \mathrm{ml}$ and $44.3 \mu \mathrm{g} / \mathrm{ml}$ at $48 \mathrm{~h} \mathrm{Fig} 2(\mathrm{~b}$ and $\mathrm{c}$ ). The percentage of apoptotic nuclei after treatment with pure hesperetin $63.18 \mu \mathrm{g} / \mathrm{ml}$ and $44.3 \mu \mathrm{g} / \mathrm{ml}$ of Au-mPEG${ }_{(5000)-S}$-HP nanoparticles at $48 \mathrm{~h}$ shows increased enormously $(\mathrm{p}<0.05)$ to $39 \%$ and $70 \%$, respectively, as revealed by nuclear condensation and fragmentation.
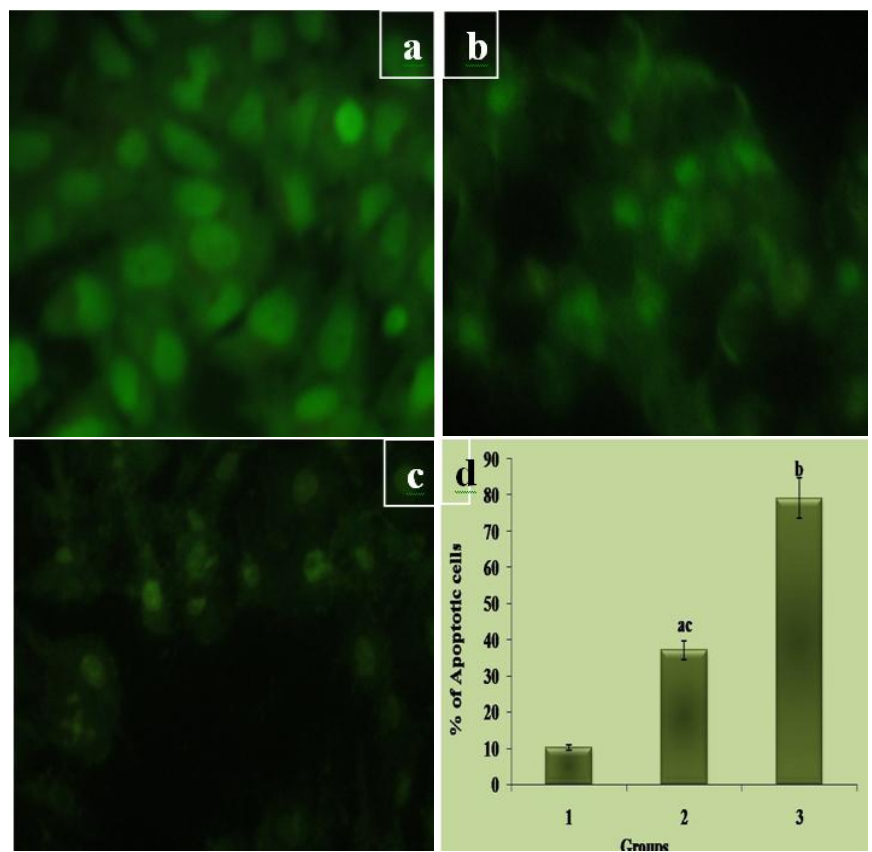

Fig. 1: Hesperetin loaded gold nanoparticles $\left(\mathrm{Au}-\mathrm{mPEG}_{(5000)}-\mathrm{S}-\mathrm{HP}\right)$ increased percentage of apoptosis of Hep3B cells analysed under fluorescence microscopy (acridine orange/ethidium bromide staining, x20). (a) Hep3B control (showing viable green fluorescent nuclei), (b) treatment with $63.18 \mu \mathrm{g} / \mathrm{ml}$ pure hesperetin at $48 \mathrm{~h}$ (showing yellow fluorescent nuclei), (c) treated with $44.3 \mu \mathrm{g} / \mathrm{ml} \mathrm{Au}-\mathrm{mPEG}_{(5000)-S}$-HP nanoparticles at $48 \mathrm{~h}$ (showing orange fluorescent nuclei), and (d) quantitative analysis shows the percentage of apoptotic cells. Results are expressed as mean \pm S.D for each group. Statistical significance at $\mathrm{p}<0.05$ compared with ${ }^{\mathrm{a}}$ group 1 , ${ }^{\mathrm{b}}$ group 2 , and ${ }^{\mathrm{c}}$ group 3 .
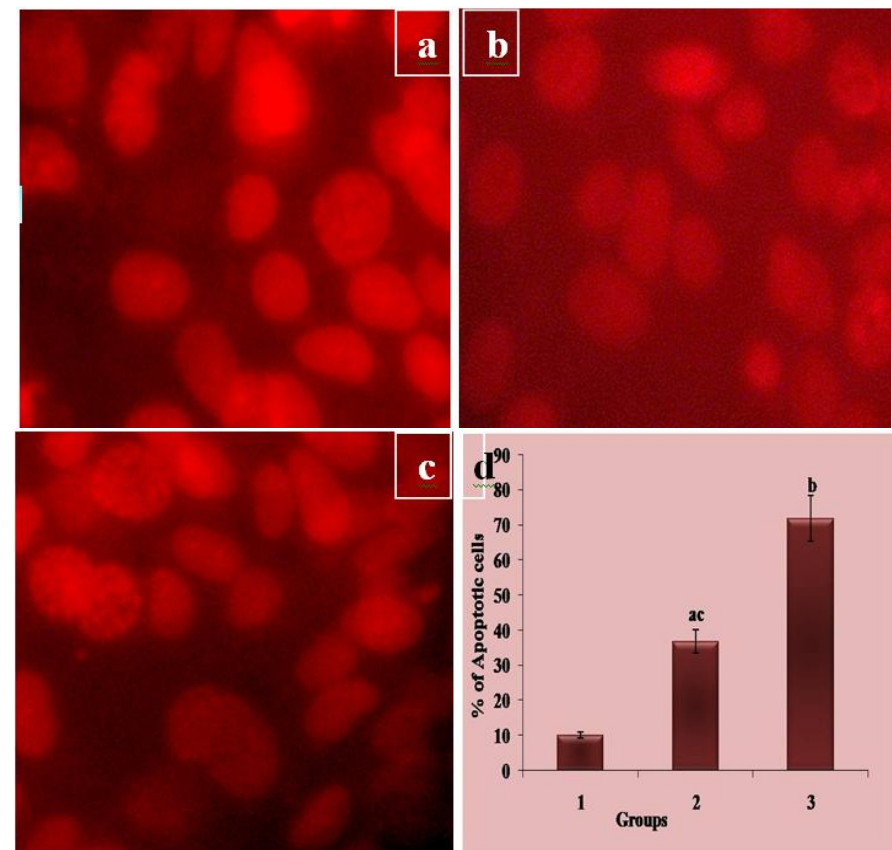

Fig. 2: Hesperetin loaded gold nanoparticles $\left(\mathrm{Au}-\mathrm{mPEG}_{(5000)}-\mathrm{S}-\mathrm{HP}\right)$ increased percentage of apoptosis of Hep3B cells analysed under fluorescence microscopy (propidium iodide staining, x20). (a) Hep3B control (shows clear nuclei), (b) treatment with $63.18 \mu \mathrm{g} / \mathrm{ml}$ at $48 \mathrm{~h}$ (nuclear condensation and fragmentation), (c) treatment with $44.3 \mu \mathrm{g} / \mathrm{ml} \quad \mathrm{Au}-\mathrm{mPEG}_{(5000)}-\mathrm{S}-\mathrm{HP}$ 
nanoparticles at $48 \mathrm{~h}$ (nuclear condensation and fragmentation). (d) representative bar chart showing percentage of apoptotic nuclei. Results are expressed as mean \pm S.D for each group. Statistical significance at $\mathrm{p}<0.05$ compared with ${ }^{\mathrm{a}}$ group 1 , ${ }^{\mathrm{b}}$ group 2 , and ${ }^{\mathrm{c}}$ group 3.

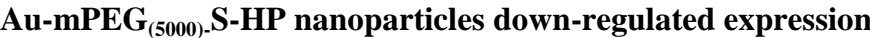 of inflammatory, metastatic and proliferation associated proteins MMP-2, MMP-9, NF-kB, PCNA, and Cyclin D1 in Hep3B cells.}

Figure 3 shows the protein expression analysis of MMP2 \& MMP-9, NF-kB PCNA, Cyclin D1 and $\beta$-Actin of control, pure hesperetin (HP) and Au-mPEG ${ }_{(5000)}$ S-HP nanoparticles treated Hep3B cells, as assessed by immunoblotting and their densitometric analysis. Polymer functionalized gold nanoparticles loaded hesperetin $\left(\mathrm{Au}-\mathrm{mPEG}_{(5000)} \mathrm{S}-\mathrm{HP}\right)$ treatment significantly decreased $(\mathrm{p}<0.05)$ the expression of NF-kB, MMP-2 \& MMP-9, PCNA and Cyclin D1 dose dependently as evident from immunoblotting and their corresponding densitometric data.

Au-mPEG ${ }_{(5000)}$ S-HP nanoparticles up-regulated expression of pro-apoptotic proteins p53, Cyt-c, Bax,Caspase-3and $\beta$-Actin with concomitant decrease levels of anti-apoptotic protein Bcl-2and survivin in Hep3B cells.

Figure 4 and 5 shows the expression levels of p53, Cyt-c, Bax, Caspase-3, Bcl-2, Survivin and $\beta$-Actin in control, pure hesperetin (HP) and Au-mPEG ${ }_{(5000)-} \mathrm{S}-\mathrm{HP}$ nanoparticles treated Hep3B cells, as assessed by immunoblotting and their densitometric analysis.

The results showed the polymer functionalized gold nanoparticles loaded hesperetin $\left(\mathrm{Au}-\mathrm{mPEG}_{(5000)} \mathrm{S}-\mathrm{HP}\right)$ treatment significantly increased $(\mathrm{p}<0.05)$ the expression of pro-apoptoic proteins p53, Cyt-c, Bax, and Caspase-3 and subsequently decreased $(\mathrm{p}<0.05)$ the expression of anti-apoptotic protein $\mathrm{Bcl}-2$ and Survivin dose dependently as evident from immunoblotting and corresponding densitometry data.

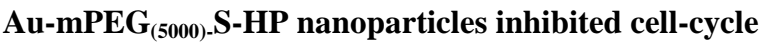 progression analysis}

Figure 6 shows the effect of hesperetin on cell-cycle regulation in Hep3B cells. Treatment with pure hesperetin 63.18 $\mu \mathrm{g} / \mathrm{ml}$ and $44.3 \mu \mathrm{g} / \mathrm{ml}$ of $\mathrm{Au}-\mathrm{mPEG}_{(5000)-} \mathrm{S}-\mathrm{HP}$ nanoparticles at $48 \mathrm{~h}$ significantly increased the proportion of cells with a reduced DNA content (sub-G0/G1 peak), indicative of apoptosis with loss of cells in the G1 phase. Incubation of the cells with $63.18 \mu \mathrm{g} / \mathrm{ml}$ of pure hesperetin and $44.3 \mu \mathrm{g} / \mathrm{ml}$ of Au-mPEG (5000)-S-HP nanoparticles at $48 \mathrm{~h}$ significantly increased the proportion of apoptotic cells from $4.91 \%$ (control), $24.87 \%(63.18 \mu \mathrm{g} / \mathrm{ml}$ of pure hesperetin) and $42.03 \%\left(44.3 \mu \mathrm{g} / \mathrm{ml}\right.$ of $\mathrm{Au}-\mathrm{mPEG}_{(5000)} \mathrm{S}-\mathrm{HP}$ nanoparticles).

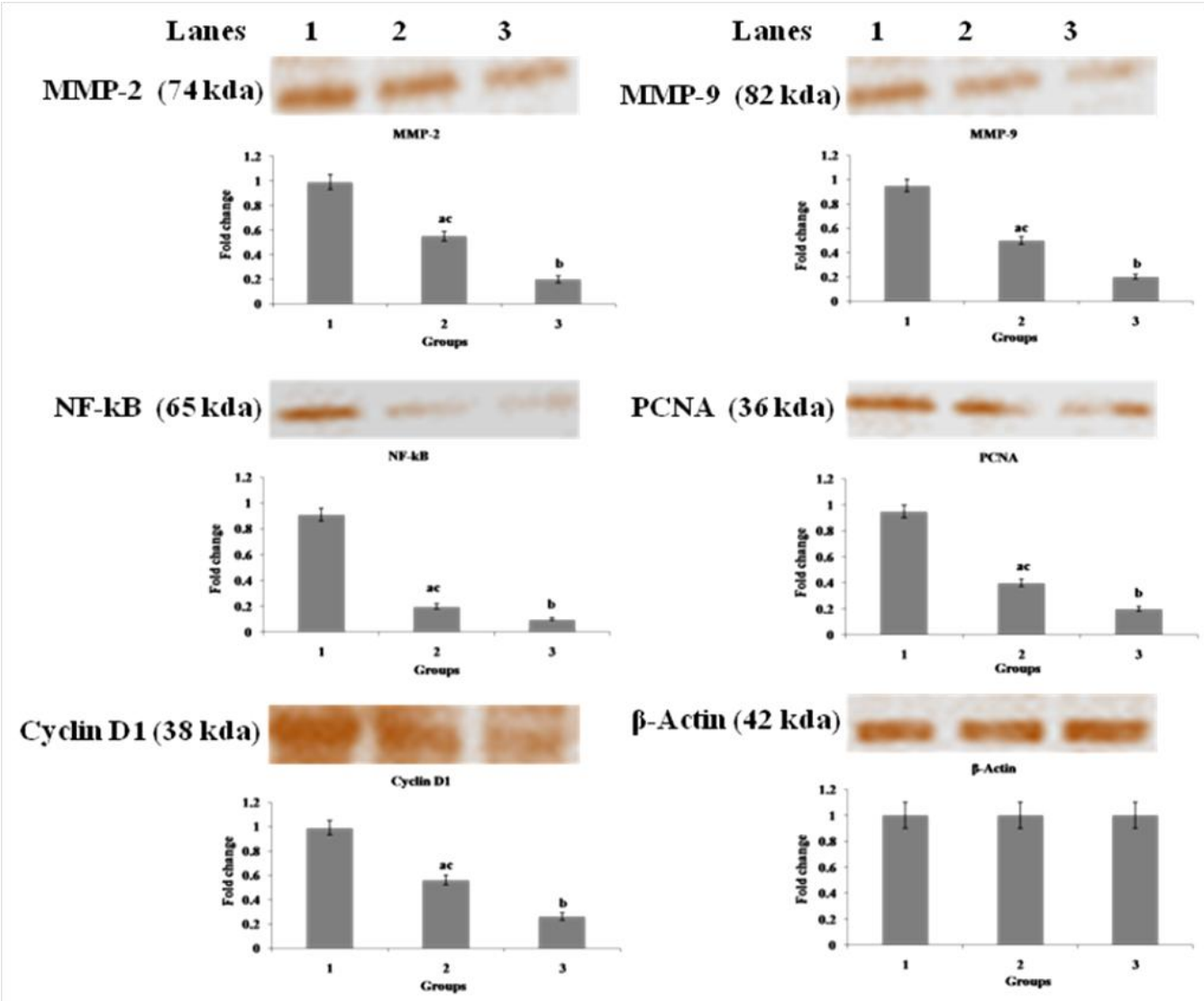

Fig. 3: Immunoblotting analysis of MMP-2, MMP-9, NF-kB, PCNA, Cyclin D1 and $\beta$-Actin in control, Hesperetin (HP) and Hesperetin loaded gold

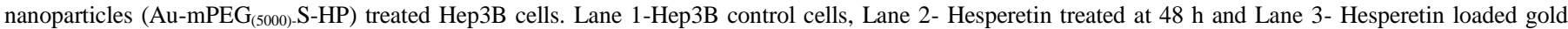
nanoparticles $\left(\mathrm{Au}-\mathrm{mPEG}_{(5000)-\mathrm{S}-\mathrm{HP})}\right.$ treated at $48 \mathrm{~h}$. Results are expressed as mean $\pm \mathrm{SD}$ for six rats in each group. Statistical significance at $\mathrm{P}<0.05$ compared with ${ }^{\mathrm{a}}$ group 1 , ${ }^{\mathrm{b}}$ group 2 , and ${ }^{\mathrm{c}}$ group 3. 


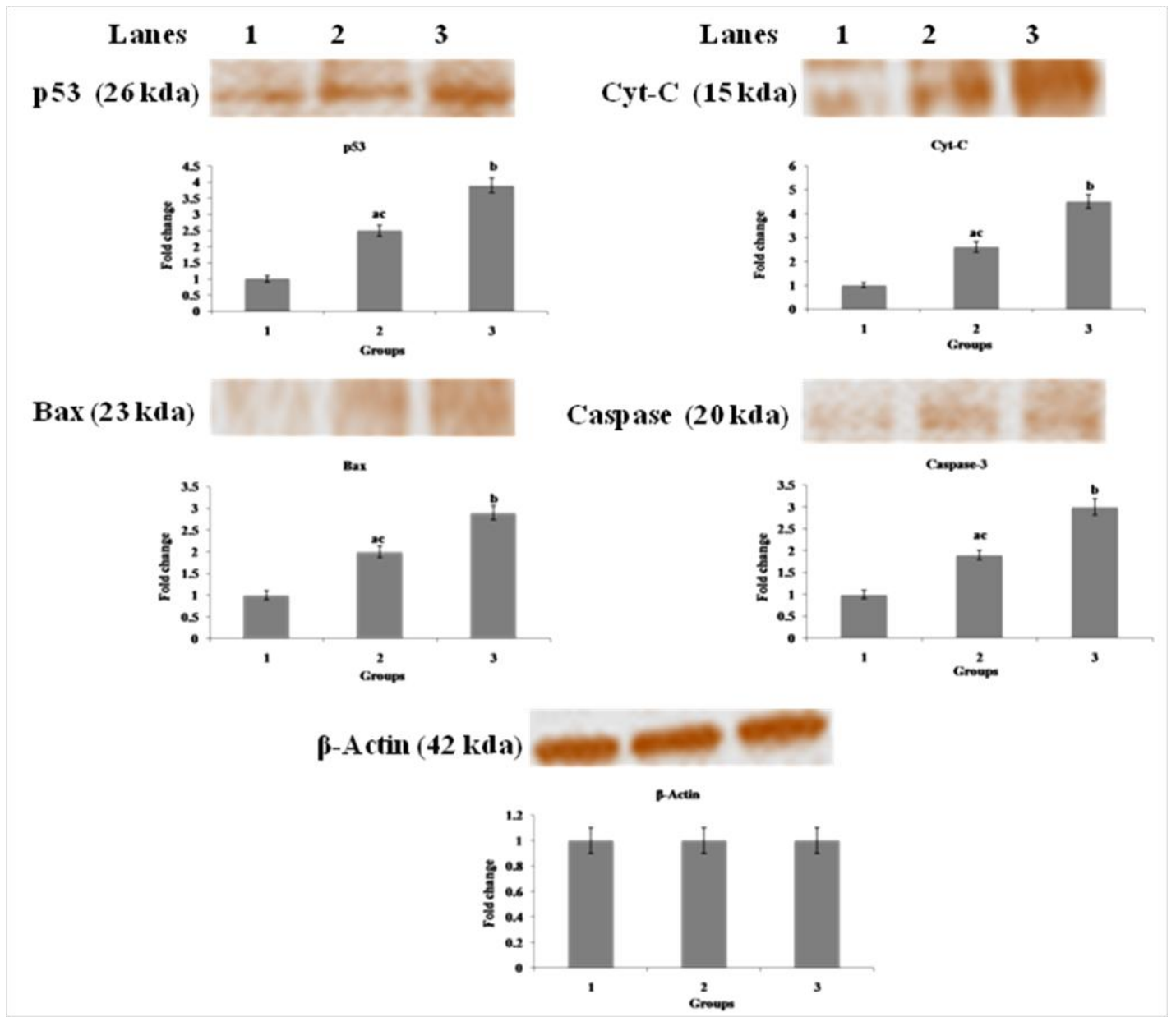

Fig. 4 Immunoblotting analysis of p53, Cyt-C, Bax, Caspase-3 and $\beta$-Actin in control, Hesperetin (HP) and Hesperetin loaded gold nanoparticles (Au-mPEG ${ }_{(5000)-}$ S-HP) treated Hep3B cells. Lane 1-Hep3B control cells, Lane 2- Hesperetin treated at $48 \mathrm{~h}$ and Lane 3- Hesperetin loaded gold nanoparticles (Au-mPEG $(5000)$-S$\mathrm{HP})$ treated at $48 \mathrm{~h}$. Results are expressed as mean \pm SD for six rats in each group. Statistical significance at $\mathrm{P}<0.05$ compared with ${ }^{\mathrm{a}}$ group 1 , ${ }^{\mathrm{b}}$ group 2 , and group 3.

\section{Lames $11 \quad 2 \quad 3$}

Bcl-2 (26 kda)

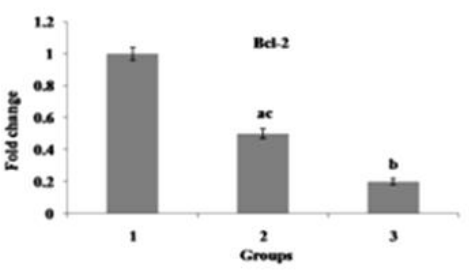

Lanes $\quad 1 \quad 2 \quad 3$

Survivin (16.5 kda)

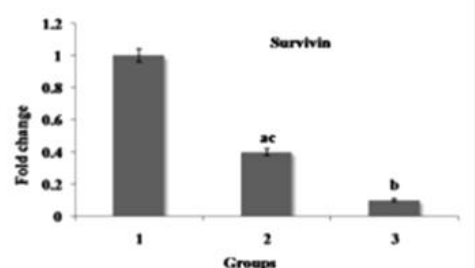

p-Actin (42 kda)
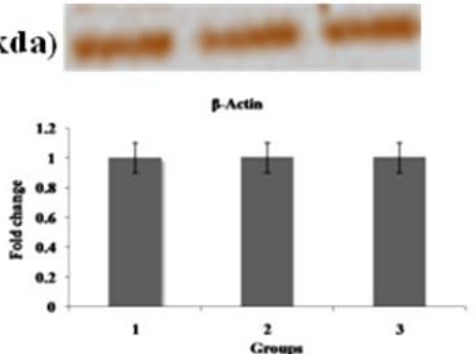

Fig. 5 Immunoblotting analysis of Bcl-2, Survivin and $\beta$-Actin in control, Hesperetin (HP) and Hesperetin loaded gold nanoparticles (Au-mPEG (5000)-S-HP) $_{\text {(n) }}$ treated Hep3B cells. Lane 1-Hep3B control cells, Lane 2- Hesperetin treated at $48 \mathrm{~h}$ and Lane 3- Hesperetin loaded gold nanoparticles (Au-mPEG ${ }_{(5000)-S}-\mathrm{HP}_{\text {) }}$ treated at $48 \mathrm{~h}$. Results are expressed as mean $\pm \mathrm{SD}$ for six rats in each group. Statistical significance at $\mathrm{P}<0.05$ compared with ${ }^{\mathrm{a}}$ group 1 , ${ }^{\mathrm{b}}$ group 2 , and ${ }^{\mathrm{c}}$ group 3 . 

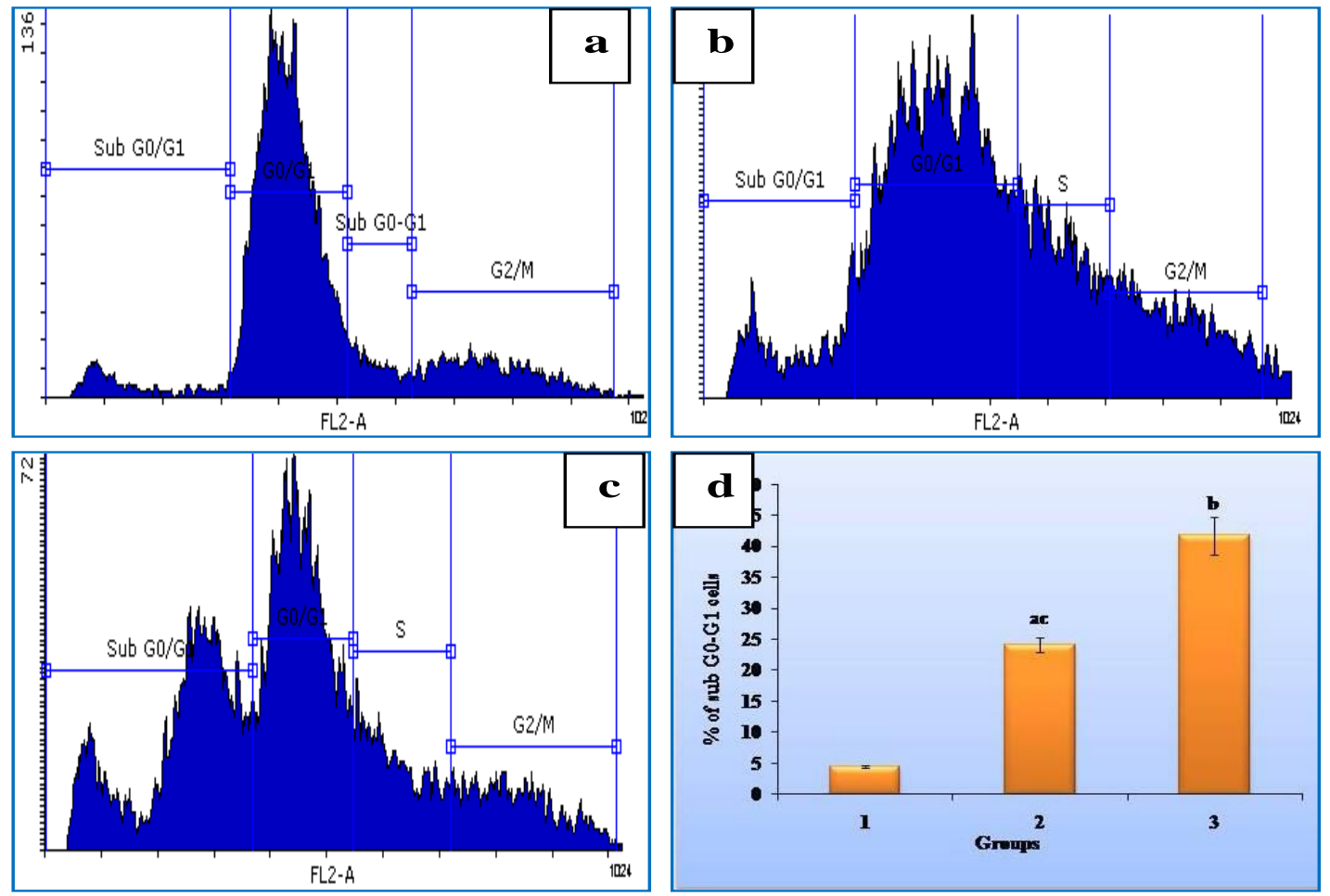

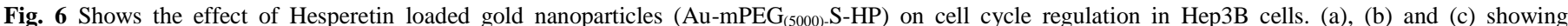
representative histogram of Hep3B control, $63.18 \mu \mathrm{g} / \mathrm{ml}$ pure hesperetin and $44.3 \mu \mathrm{g} / \mathrm{ml}$ of Au-mPEG (5000) $-S-H P$ nanoparticles respectively. (d) quantitative

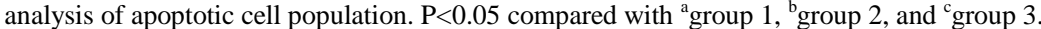

\section{DISCUSSION}

Hepatocellular carcinoma $(\mathrm{HCC})$ is a serious problem in developing countries, accounting for $81 \%$ of the total cases in the world and $54 \%$ of the total cases in China (Parkin et al., 1990). Furthermore, these tumors are quite resistant to radiotherapy and chemotherapy (Blum, 2002). No effective postoperative adjuvant chemotherapeutic agent is available so far. The newly developed antineoplastic agents, such as capecitabine (Murata et al., 2003), are expected to increase the therapeutic effect on liver cancer. However, the cost of treatment is expensive and the therapeutic effect is uncertain, indicating that more clinical data and trials are needed. Since almost all chemotherapeutics have side effects, the tolerance of patients to chemotherapy is usually poor (Dizon and Kemeny, 2002). More over most of the natural anticancer drugs have poor solubility, poor bioavailability and side effects. Therefore, to achieve maximum response of a chemopreventive agent, novel strategies are required to enhance the solubility and bioavailability of potentially useful agents and reduce the perceived toxicity. So under the guidance of Polymer functionalized gold nanoparticles loaded drug provided a new method for the treatment of cancer. Gold nanoparticles possess biological activities like antioxidant, anti-inflammatory, antiangiogenesis and anticancer properties (Barath ManiKanth et al., 2010). Recently, the functionalized AuNPs were synthesized through different stabilizing and capping agents and showed the potential in several applications (Chao-Ching Chang et al., 2008). In comparison with the other stabilizing agents like surfactants, flavonoids, alkaloids, etc. PEGylation is one of the most commonly used functionalization methods where a layer of PEG is coated on the surface of AuNPs or in conjunction with other molecules such as biotin, peptides or oligonucleotides. (Esther et al; 2001) has developed a hetero-bifunctional PEGlyated AuNPs, where the AuNPs was functionalized with thiol group on one end and cumarin a fluorescent dye on the other. Hence, it is clear that the binding ability of the AuNPs to the cell membrane and the functionalization of the polymer on the AuNPs make it to serve as a good drug carrier (Takae et al., 2005 and Ishii et al., 2004).

In the present study, the hesperetin-loaded polymer functionalization gold nanoparticles inhibited proliferation and induced apoptosis in the human hepatocellular carcinoma cell line Hep3B was assessed by procedures, such as ethidium bromide/acridine orange staining and propidium iodide staining. These results clearly identified that $\mathrm{Au}-\mathrm{mPEG}_{(5000)} \mathrm{S}-\mathrm{HP}$ nanoparticles treatment induced apoptosis. Mast cells activate matrix metalloproteinase's (MMPs) expression (Tchougounova et al., 2005). MMPs has found to be increased in virtually every type of human cancer and correlates with advanced stage, invasive and metastatic properties and resulting in poor prognosis. MMPs are required for migration, metastatic growth and angiogenesis for 
better growth (Rundhaug, 2003). Spreading of cancer cells to the surrounding environment is one of the primary reasons for mortality in liver cancer. From the results of the present research it is evident that polymer functionalized gold naoparticles loaded hesperetin $\left(\mathrm{Au}-\mathrm{mPEG}_{(5000)} \mathrm{S}-\mathrm{HP}\right)$ treatment much more suppresses the MMP-2 and MMP-9 proteins expression in Hep3B cell, thereby preventing the local spreading cancer cells and proving anti-metastatic effect. In present study, it can be speculated that increase in the levels of mast cells responsible for the increased levels of MMP-2 and MMP-9 in the control Hep3B cells but in the Au-mPEG ${ }_{(5000)} \mathrm{S}-\mathrm{HP}$ nanoparticles treated cells shows decreased mast cell number thereby might have decrease the expression of MMP-2 and MMP-9. Nuclear factor- kappa B (NF$\mathrm{kB}$ ) is a ubiquitous transcription factor that is activated by a variety of cytokines and mitogens, and is a key regulator in the inflammatory response to infection. Au-mPEG ${ }_{(5000)-} \mathrm{S}-\mathrm{HP}$ nanoparticles treated cells showing low levels of NF-kB suggesting the efficacy to inhibit the upregulation of these activated proteins when compared with Hep3B control cells. Hesperetin loaded gold nanoparticles acts as an anti-inflammatory agent hence; it might be a better therapeutic strategy in conjugation with the usage of chemopreventive agents. Proliferating cell nuclear antigen (PCNA) plays a pivotal role in cell proliferation. Over expression of PCNA with high frequency is a reliable marker for evaluating malignant grade or stages of tumor differentiation, assessment of tumor progression as well as for early detection, patient's prognosis of HCC, predicting recurrence time and diagnosis of the pathology ( $\mathrm{Ng}$ et al., 1994). Cyclin D is a major regulator of the progression of cells into the proliferative stage of the cell cycle (Weinberg at al., 1995). Cyclin D1 over expression of transgenic mice is associated with rapidly progressing development of hepatocellular adinomas and carcinomas (Deane at al., 2001). In the present study the elevated expression of PCNA and Cyclin D1 were observed in Hep3B cells reflects hyper-proliferative activity of the tumor cells. Reducing cell proliferation is one of the hallmarks of cancer chemoprevention and thus Au-mPEG (5000)-S-HP nanoparticles administration resulted in decreased expression of these proliferative markers in Hep3B cells, which clearly revealed its better anti-proliferative activity during hepatocarcinogenesis.

Apoptosis is regulated by some genes or other factors (Kerr et al., 1994). Bax, Bcl-2 and p53 are the main trigger genes of apoptosis (Keane at al., 1999). p53 is a 53-kda nuclear phospho protein that binds to DNA to act as a transcription factor, controls cell proliferation and DNA repair. Alteration in p53 gene is the most frequently identified mutation in human cancer. Loss of p53 function allows cells with damaged DNA to continue to proliferate and refore, it is associated with tumour progression (Greenblatt et al., 1994). It is estimated that in excess of 100 genes are regulated by 553 protein, many of which can promote growth arrest or apoptosis. Therefore, when DNA damage is more in amount, this checkpoint protein p53 commits the damaged cells to an active process of cell death known as apoptosis. In the present study there was decreased protein of p53 in control Hep3B cells which might be the reason for decreased apoptosis and increased proliferation

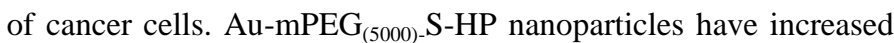
the expression of tumor suppressor protein p53 and it causes inhibition of cell proliferation and induction of apoptosis (Devanand Venkatasubbu et al., 2012).

Anti-apoptotic Bcl-2 localizes predominantly at the mitochondrial and inhibits apoptosis. Bax, a pro-apoptotic protein resides in the cytoplasm and stimulates cell death after translocation to mitochondria. The balance between anti-apoptotic and pro-apoptotic protein expression determines the susceptibility of the cell to apoptogenic stimuli (Hengartnwer, 2000). Bcl-2 is an upstream effectors molecule in the apoptotic pathway and is identified as a potent suppressor of apoptosis. It has been reported that Bcl-2 is found at inappropriately high levels in more than half of all human cancers. The capacity of Bcl-2 and Bax to compete for one another via heterodimers suggests a reciprocal relationship in which Bcl-2 monomers or homodimers favour survival and Bax homodimers favor death (Oltvain et al., 1993). The ion channel perforation activity of Bcl-2 and Bax may control apoptosis by influencing the permeability of the membranes and cytochrome $\mathrm{c}$ release from mitochondria. Over expression of Bcl-2 blocks cytochrome $\mathrm{c}$ release in response to a variety of apoptotic stimuli (Cory et al., 2003). Down regulation of Bcl-2 thus contributes to cytochrome c release from mitochondria. Moreover, Bcl-2 heterodimerization with Bax exerts dominant negative inhibition of pro-apoptotic Bax activity. Therefore, when the Bcl-2 expression level is low and the Bax expression level is maintained, homodimers of Bax will always be found and apoptosis will be stimulated (Teoh et al., 1999). In the present study there was increased expression of $\mathrm{Bcl}-2$ with subsequently decreased expression of Bax was seen in control Hep3B cells which indicate the diminished apoptosis. Au-mPEG ${ }_{(5000)} \mathrm{S}-\mathrm{HP}$ nanoparticles treatment significantly decrease the level of Bcl-2 with subsequent increase in Bax which might be due to the ability of hesperetin loaded gold nanoparticles to induce p53 expression because p53 is a positive transcriptional activator for Bax gene and a negative transcriptional activator for Bcl-2 gene. Thus, the activation of p53 pathway is much more efficacy in $\mathrm{Au}_{-\mathrm{mPEG}_{(5000)}-\mathrm{S}-\mathrm{HP}}$ nanoparticles might lead to the down regulation of Bcl-2 and upregulation of Bax. Survivin inhibits apoptosis mainly through targeting terminal effector caspase-3 activity in the apoptotic protease cascade Cancer-specific expression of survivin, coupled with its importance in inhibiting cell death and in regulating cell division, makes it a useful diagnostic marker of cancer and a potential target for cancer treatment. Recently, studies have set out to evaluate the possibility of targeting survivin function in vivo as an anticancer strategy in which it has been shown that inhibition of survivin could effectively inhibit de novo tumour formation and progression (Kanwar et al., 2001). Here, Au-mPEG ${ }_{(5000)}$ S-HP nanoparticles treatment significantly decreased the level of this protein, which might be due to the ability of $\mathrm{Au}-\mathrm{mPEG}_{(5000)} \mathrm{S}-\mathrm{HP}$ nanoparticles to up-regulate the level of p53 as survivin is negatively regulated by $\mathrm{p} 53$. The effect of Au- $\mathrm{PPEG}_{(5000)-} \mathrm{S}-\mathrm{HP}$ nanoparticles on cell-cycle regulation in Hep3B cells shows that 
the increased the proportion of cells with a reduced DNA content (sub-G0/G1 peak), indicative apoptosis with loss of cells after endonuclease cleavage. After staining with propidium iodide, these cells would have take up less stain and appear sub-G0/G1 (that is to the left of the G0/G1 peak).

In conclusion, Polymer functionalized hesperetin conjugated gold nanoparticles $\left(\mathrm{Au}-\mathrm{mPEG}_{(5000)} \mathrm{S}-\mathrm{HP}\right)$ should be a better chemotherapeutic effect as compare with pure hesperetin (HP) on Hep3B cells.

In addition, $\mathrm{Au}-\mathrm{mPEG}_{(5000)} \mathrm{S}-\mathrm{HP}$ nanoparticles attenuates hepatocellular carcinoma through inhibition of cell proliferation and tumor metastasis. This is evidenced by the down-regulation of PCNA, Cyclin D1, MMP-2, and MMP-9, over expression of these proteins associated with tumorigenesis. The overall conclusion, suggest that $\mathrm{Au}-\mathrm{mPEG}_{(5000)} \mathrm{S}-\mathrm{HP}$ nanoparticles possess better antiinflammatory, ant-proliferative and potentially useful drug carrier system for delivery against hepatocellular carcinoma in invivo.

\section{ACKNOWLEDGMENTS}

Financial support and sponsorship: Author Gokuladhas K. thanks Indian Council of Medical Research (ICMR), New Delhi, India, for the financial assistance in the form of Senior Research Fellowship (SRF), File No. 3/2/156/2011/NCD-III.

Conflict of Interests: There are no conflicts of interest.

\section{REFERENCES}

Aranganathan S, Nalini N. Efficacy of the potential chemopreventive agent, Hesperetin (citrus flavanone), on 1, 2dimethylhydrazine induced colon carcinogenesis. Food and chemical toxicology, 2009; 47:2594-2600.

Barath ManiKanth S, Kalishwaralal K, Sriram M, Ram Kumar Pandian SB, Youn HS, Eom SH, Gurunathan S. J Biomed Nanotechnol, 2010; 6:1-15.

Blum HE. Molecular targets for prevention of hepatocellular carcinoma. Dig Dis, 2002; 20:81-90.

Chandramohan KVP, Gunasekaran P, Varalakshmi E, Hara Y, Nagini. In vitro evaluation of the anticancer effect of lactoferrin and tea polyphenol combination on oral carcinoma cells. Cell Biol. Int, 2007; 31:599-608.

Chao-Ching Chang, Pei-Huan Chen, Chih-Ming Chang. Preparation and characterization of acrylic polymer-nanogold nanocomposites from 3-mercaptopropyltrimethoxysilane encapsulated gold nanoparticles. J Sol-Gel Sci Technol, 2008; 47:268-273.

Cory S, Huang DC, Adams JM. The Bcl-2 family:roles in cell survival and oncogeneis. Oncogene, 2003; 22:8590-8607.

Deane NG, Parker MA, Aramandla R, Diehl L, Lee WJ, Washington MK, Nanney LB, Shyr Y, Beauchamp RD. Hepatocellular carcinoma results from chronic cyclin D1 over expression in transgenic mice. Cancer res, 2001; 61:5389-5395.

Devanand Venkatasubbu G, Ramasamy S, Avadhani GS, Palanikumar L, Kumar J. Size-mediated Cytotoxicity of nanocrystalline titanium dioxide, Pure and zinc doped hydroxyapatite nanoparticles in Human hepatoma cells. Journal of Nanoparticle Research, 2012; (14)4:819.

Devanand Venkatasubbu G, Ramasamy S, Pramod Reddy G, Kumar J. Acute and Sub-chronic toxicity analysis of surface modified paclitaxel attached hydroxyapatite and titanium dioxide nanoparticles. International Journal of Nanomedicine, 2015; 10:137-148.

Devanand Venkatasubbu G, Ramasamy S, Pramod Reddy G, Kumar J. In vitro and In vivo anticancer activity of surface modified paclitaxel attached hydroxyapatite and titanium dioxide nanoparticles. Biomedical Microdevices, 2013; 15(4):711-726.

Dizon DS, Kemeny NE. Intrahepatic arterial infusion of chemotherapy: clinical results. Semin Oncol, 2002; 29:126-135.

Esther K, Andreas H, Ronald J. Quinn Similar interactions of natural products with biosynthetic enzymes and therapeutic targets could explain why nature produces such a large proportion of existing drugs. Nat. Prod, 2001; 1483-1492.

Fauziah OP, Hanachi S, Yogespriya, Asmah R. Reducing effect of Strobilanthes crispus leaf extract in hepatocarcinogenesis rats. Int $\mathrm{J}$ Cancer Res, 2005; 1:109-112.

Formica JV, Regelson W. Review of the Biology of Quercetin and related Bioflavonoids. Food Chem. Toxicol, 1995; 33:1061-1080.

Gohel A, McCarthy MB, Gronowicz G. Estrogen prevents glucocorticoid-induced apoptosis in osteoblasts in vivo and in vitro. Endocrinology, 1999; 140:5339-5347.

Gokuladhas K, Jayakumar S, Madankumar A, Rajan B, Elamaran R, Pramila S, Devaki T. Synthesis and characterization of biocompatible gold nanoparticles stabilized with hydrophilic polymer coated hesperetin drug for sustained drug delivery to treat hepatocellular carcinoma- derived cancer cells. International journal of pharmacy research, 2014; 8(2):98-105.

Greenblatt MS, Bennett WP, Hollstein M, Harris CC. Mutation in the p53 tumor suppressor gene: clues to cancer etiology and molecular pathogenesis. Cancer Res, 1994; 54: 4855-4878.

Hengartnwer MO. The biochemistry of Apoptosis. Nature, $2000 ; 407: 770-776$.

Horvathova E, Sramkova M, Labaj J, Slamenova D. Study of cytotoxic,genotoxic and DNA protective effects of selected plant essential oils on human cells cultured in vitro. Neuro Endocrinol Lett, 2006; 27(2):44-47.

Ishii T, Otsuka H, Kataoka K, Nagasaki Y. Preparation of functionally PEGylated gold nanoparticles with narrow distribution through autoreduction of auric cation by alphabiotinyl-PEG-block-[poly (2-N, N-dimethylamino) ethyl methacrylate)]. Langmuir, 2004; 20:561564.

Jemal A, Bray F, Center MM, Ferlay J, Ward E, Forman D. Global Cancer Statistics. CA. A Cancer Journal for Clinicians, 2001; 61:69-90.

Kanaze FI, Kokkalou E, Niopas I, Georgarakis M, Stergiou A, Bikiaris D. Dissolution enhancement of flavonoids by solid dispersion in PVP and PEG matrixes: A comparative study. Journal of Applied Polymer Science, 2006; 102:460-471.

Kanwar JR, Shen WP, Kanwar RK, Berg RW, Krissansen CW. Effects of survivin antagonists on growth of established tumors and B7-1 immunogene therapy. J. Natl. Cancer Inst, 2001; 93:1541-1552.

Karkabounas S, Sofis G, Evangelou A. Implication of free radicals in platelet aggregation: antiplatelet effects of free radical scavengers ex vivo. Epith Klin Farmacol Farmakokin, 1996; 10:84-91.

Keane MM, Ettenberg SA, Nau MM, Russell EK, Lipkowitz S. Chemotherapy augments TRAIL-induced apoptosis in breast cell lines. Cancer Res, 1999; 59:734-741.

Kerr JF, Winterford CM, Harmon BV. Apoptosis. Its significance in cancer and cancer therapy. Cancer, 1994; 73: 2013-2026.

Kumari A, Yadav SK, Yadav SC. Biodegradable polymeric nanoparticles based drug delivery systems. Colloids Surf B Biointerfaces, 2010; 75:1-18.

Li L, Tang F, Liu H, Liu T, Hao N, Chen D, Teng X, He J. In vivo delivery of silica nanorattle encapsulated docetaxel for liver cancer therapy with low toxicity and high efficacy. ACS Nano. 2010; 4(11):68746882.

Lin Q, Chen J, Ng KK, Cao W, Zhang Z, Zheng G. Imaging the cytosolic drug delivery mechanism of HDL like nanoparticles. Pharm Res, $2014 ; 31: 1438-1449$. 
London WT, McGlynn KA, Liver cancer, in: Schottenfeld D, Fraumeni JF (Eds.). Cancer Epidemiology and Prevention, third ed., 2006; Oxford University Press, Inc., New York, 763-786.

Murata K, Shiraki K, Kawakita T, Yamamoto N, Okano H, Nakamura M, Sakai T, Deguchi M, Ohmori S, Nakano T. Low-dose chemotherapy of cisplatin and 5-fluorouracil or doxorubicin via implanted fusion port for un respectable hepatocellular carcinoma. Anticancer Res, 2003; 23:1719-1722.

Nam HY, Kwon SM, Chung H, Lee SY, Kwon SH, Jeon H, Kim Y, Park JH, Kim J, Her S, Oh YK, Kwon IC, Kim K, Jeong SY. Cellular uptake mechanism and intracellular fate of hydrophobically modified glycol chitosan nanoparticles. J Control Release, 2009; 135:259267.

Ng IO, Lai EC, Fan ST. Prognostic significance of proliferating cell nuclear antigen expression in hepatocellular carcinoma. Cancer, 1994; 73:2268-2274

Oltvain ZN, Milliman CL, Korsmeyer SJ. Bcl-2 heterodimerizes in vivo with a conserved homolog, Bax, that accelerates programmed cell death. Cell, 1993; 74:609-619.

Panyam J, Labhasetwar V. Biodegradable nanoparticles for drug and gene delivery to cells and tissue. Adv Drug Deliv Rev, 2003; 55:329-347.

Panyam J, Zhou WZ, Prabha S, Sahoo SK, Labhasetwar V. Rapid endo-lysosomal escape of poly (DL-lactideco-glycolide) nanoparticles: implications for drug and gene delivery. FASEB J, 2002; 16:1217-1226.

Parkin DM, Pisani P, Ferlay J. Estimates of the worldwide incidence of 25 major cancers in 1990. Int J Cancer ,1990; 80:827-841.

Rasola A, Geuna M. A flow cytometry assay simultaneously detects independent apoptotic parameters. Cytometry, 2001; 45:151-157.

Rundhaug JE. Matrix metalloproteinases, angiogenesis and cancer: commentary re: A.C. Lockhart et al., Reduction of wound angiogenesis in patiens treated with BMS-275291, a broad spectrum matrix metalloproteinase inhibitor. Clin cancer res, 2003; 9:551-554.

Singhal A, karachristos A, Bromberg M, Daly E, Maloo M, Jain AK. Hypercoagulability in end-stage liver disease: prevalence and its correlation with severity of liver disease and portal vein thrombosis. Clin App Thromb Hemost, 2012; 18(6):594-8.

Sunderland CJ, Steiert M, Talmadge JE, Derfus AM, Barry SE. Targeted nanoparticles for detecting and treating cancer. Drug Development Research, 2006; 67:70.
Takae S, Akiyama Y, Otsuka H, Nakamura T, Nagasaki Y, Kataoka K. Ligand density effect on biorecognition by PEGylated gold nanoparticles: Regulated Interaction of RCA (120) lectin with lactose installed to the distal end of tethered PEG strands on gold surface. Biomacromolecules, 2005; 6:818-824.

Tchougounova E, Lundequist A, Fajardo I. A key role for mast cell chymase in the activation of pro-matrix metalloprotease- 9 and promatrix metalloprotease-2. J Biol Chem, 2005; 280:9291-9296.

Teoh PL, Azimahtol Hawariah LP. Effects of styrylpyrone derivative (SPD) on expression of Bcl-2 and Bax genes in human ovarian carcinoma cell line, Caov-3. Malays Appl Biol, 1999; 28:107-111.

Tsai WL, Chung RT. Viral hepatocarcinogenesis. Oncogene, 2010; 29(16):2309-24.

Weinberg RA. The retinoblastoma protein and cell cycle control. Cell, 1995; 81:323- 330.

Wellington K, Jarvis B. Silymarin: a review of its clinical properties in the management of hepatic disorders. BioDrugs, 2001; $15: 465-489$.

Wilcox LJ, Borradaile NM, Huff MW. Antiatherogenic properties of naringenin, a citrus flavonoid. Cardiovasc Drug Rev, 1999; 17:160-78

Xu P, Gullotti E, Tong L, Highley CB, Errabelli DR, Hasan T, Cheng JX, Kohane DS, Yeo Y. Intracellular drug delivery by poly(lacticco-glycolic acid) nanoparticles, revisited. Mol Pharm, 2009; 6:190-201.

\section{How to cite this article:}

Krishnan G, Subramaniyan J, Subramani PC, Thiruvengadam D. Nanochemopreventive effect of polymer functionalized gold nanoparticles containing hesperetin drug inhibited proliferation and induced apoptosis in Hep3B cells. J App Pharm Sci, 2016; 6 (12): 114-123. 